\title{
A TAT-conjugated peptide inhibitor of polo-like kinase 1 for in vivo tumor imaging
}

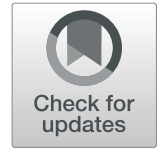

Min Su Yim ${ }^{1,2}$, Eun Ju Son ${ }^{1}$, Hak Nam Kim ${ }^{1}$ and Eun Kyoung Ryu ${ }^{1,2,3^{*}}$

\begin{abstract}
Early detection and accurate diagnosis are essential for the effective prevention and treatment of tumors. Optical imaging methods can provide real-time and high-resolution in vivo images for tumor diagnostic applications. ProLeu-His-Ser-Thr $\left(\mathrm{PO}_{3} \mathrm{H}_{2}\right)(\mathrm{PLHSpT})$ is an inhibitor of polo-like kinase 1, which is overexpressed in various tumors, and the transactivator of transcription (TAT) is a peptide known to penetrate tumor cells. In this study, we used a fragment of the TAT sequence, YARVRRRGPRR, to produce a YARVRRRGPRR-conjugated PLHSpT peptide using solidphase peptide synthesis. Subsequently, the cyanine 5 NHS ester (Cy5) fluorescent dye was attached to YARVRRRGPRRPLHSpT (1) to obtain the Cy5-YARVRRRGPRRPLHSpT peptide (2), which was used to identify tumor targets through optical imaging. 2 was injected into HeLa xenograft tumor-bearing mice. After in vivo imaging at 3 $\mathrm{h}, 6 \mathrm{~h}$, and $24 \mathrm{~h}$ post-injection, mice were sacrificed for ex vivo fluorescence intensity assessment. Optical imaging scans of 2 revealed significantly high uptake by tumor cells at all in vivo scan times. The highest fluorescence intensity difference between tumor and muscles was observed at $6 \mathrm{~h}$. Ex vivo results also showed a high variation in the tumor-to-muscle uptake ratios at $6 \mathrm{~h}$. In conclusion, we synthesized and evaluated 2 for cancer diagnosis in mice. Our optical imaging results demonstrated that 2 has remarkable cancer-detection ability in vivo, establishing this peptide as a potential imaging probe for tumor diagnosis.
\end{abstract}

Keywords: Peptide inhibitor, Tumor diagnosis, Optical imaging, Polo-like kinase 1, Transactivator of transcription, YARVRRRGPRR-conjugated PLHSpT peptide, Imaging probe

\section{Introduction}

Imaging techniques have long been considered an effective approach for disease diagnosis. They include magnetic resonance imaging, positron emission tomography, single-photon emission computed tomography, computed tomography, and ultrasonography, among others (Long and Bulte 2009; Margolis et al. 2007; Sauter et al. 2010; Tapfer et al. 2012). These techniques have improved treatment capabilities by enabling the early detection of diseases. One of the most attractive advantages of these methods is that they can monitor biological and anatomical changes in the body as well as detect disease in vivo and non-invasively. Among the existing imaging tools, fluorescence imaging has been mostly used for the identification of remarkably sensitive

\footnotetext{
* Correspondence: ekryu@kbsi.re.kr

${ }^{1}$ Division of Bioconvergence Analysis, Korea Basic Science Institute, Ochang, Cheongju 28119, Korea

${ }^{2}$ Bio-Analytical Science, University of Science and Technology, 217 Gajeong-ro Yuseong-gu, Daejeon 34113, Korea

Full list of author information is available at the end of the article
}

and specific biomarkers associated with various types of diseases in vivo and in vitro (Rehemtulla et al. 2000). Moreover, fluorescence imaging is among the most convenient imaging tools in terms of availability, efficiency, and applicability in the research field (Contag et al. 2000). However, the resolution provided by the fluorescence imaging of deep tissues is a limiting factor for the detection of disease lesions for clinical application (Yang et al. 2000).

Peptide drug discovery has received increasing attention in recent years. Focus has been specially given to specific receptor targets, proteases, and protein-protein interactions. A great number of peptides and peptidomimetic drugs have been synthesized over the past three decades, and solid-phase peptide synthesis (SPPS) methods have been developed for the production of peptides with high yield and purity (Craik et al. 2013). However, there are still several limitations for the treatment of diseases using peptide drugs, such as cell permeability and access to intracellular targets. Many researchers 
have tried to solve these problems by focusing on cell-permeabilizing peptides and drug delivery systems. For instance, the transactivator of transcription (TAT) peptide, or cell-penetrating peptide, has been shown to penetrate cells and deliver a variety of cargoes, including proteins, peptides, and nucleic acids (Gump and Dowdy 2007).

Polo-like kinase 1 (Plk1) regulates the cell cycle during mitosis and controls bipolar spindle formation, chromosome segregation, and cytokinesis (Barr et al. 2004; Dai 2005; Liu et al. 2011). Plk1 is overexpressed in many tumors and has been targeted as a potential anticancer agent (Takai et al. 2005). The phosphopeptide Pro-LeuHis-Ser- $\mathrm{Thr}\left(\mathrm{PO}_{3} \mathrm{H}_{2}\right)(\mathrm{PLHSpT})$ is a selective inhibitor of the Plk1 polo-box domain (PBD). It binds to Plk1 with high affinity $\left(K_{\mathrm{d}}=0.445 \mu \mathrm{M}\right)$ and induces apoptosis in cancer cells. However, PLHSpT showed limitations as an anticancer agent due to its low cancer-cell membrane penetration. To overcome this disadvantage, we used the YGRKKRRQRRR cell-penetrating peptide, which is a fragment of the full TAT protein (amino acids 47-57) (Gump and Dowdy 2007), to design the Plk1-targeting YARVRRRGPRR-conjugated PLHSpT phosphopeptide (1) (Fig. 1). Moreover, we labeled 1 with the cyanine 5 NHS ester fluorescent dye (Cy5), giving rise to Cy5YARVRRRGPRRPLHSpT (2), to diagnose tumors in vivo by optical imaging.

\section{Methods}

Diisopropylethylamine (DIEA), N,N-dimethylformamide (DMF), ethylenediamine, piperidine, triisopropylsilane
(TIS), and trifluoroacetic acid (TFA) were purchased from Sigma-Aldrich (St. Louis, MO, USA). O-Benzotriazole-1yl- $N, N, N^{\prime}, N^{\prime}$-tetramethyluronium hexafluorophosphate (HBTU), hydroxybenzotriazole (HOBt), and Rink Amide MBHA resin (100-200 mesh, $0.50 \mathrm{mmol} / \mathrm{g}$ ) were purchased from Bead Tech (Gyeonggi, Korea). Cyanine 5 NHS ester was purchased from Lumiprobe (MD, USA).

Mass spectra were obtained by matrix-assisted laser desorption/ionization time-of-flight (MALDI-TOF) mass spectrometry (4700 Proteomics Analyzer, Applied Biosystems, USA) by the Korea Basic Science Institute (KBSI, Korea). Fluorescence imaging was performed with an In Vivo Imaging System (IVIS, PerkinElmer, USA).

\section{Synthesis of 1 and 2}

All peptides were manually synthesized according to the SPPS procedure (Ahn et al. 2014; Kim et al. 2014). To synthesize peptide 1, Rink amide MBHA resin (200 $\mathrm{mg}, 0.5 \mathrm{mmol} / \mathrm{g}, 0.1 \mathrm{mmol})$ was swollen in DMF $(2 \mathrm{~mL}$, $30 \mathrm{~min}$ ) before synthesis. The resin was treated three times with $20 \%(v / v)$ piperidine in DMF for 10 min each time and washed with DMF five times. For the coupling of amino acids, 5 equivalents of Fmoc-amino acids relative to resin loading (5 equiv.), HBTU (5 equiv.), $\mathrm{HOBt}$ (5 equiv.), and DIEA (5 equiv.) were dissolved in DMF $(2 \mathrm{~mL})$, and this solution was treated with the resin for $2 \mathrm{~h}$. After the coupling reaction, the resin was washed with DMF five times. The Fmoc deprotection and coupling steps were repeated until the desired peptide sequence was obtained. After conjugation of the last amino acid, the synthesized peptide was cleaved from

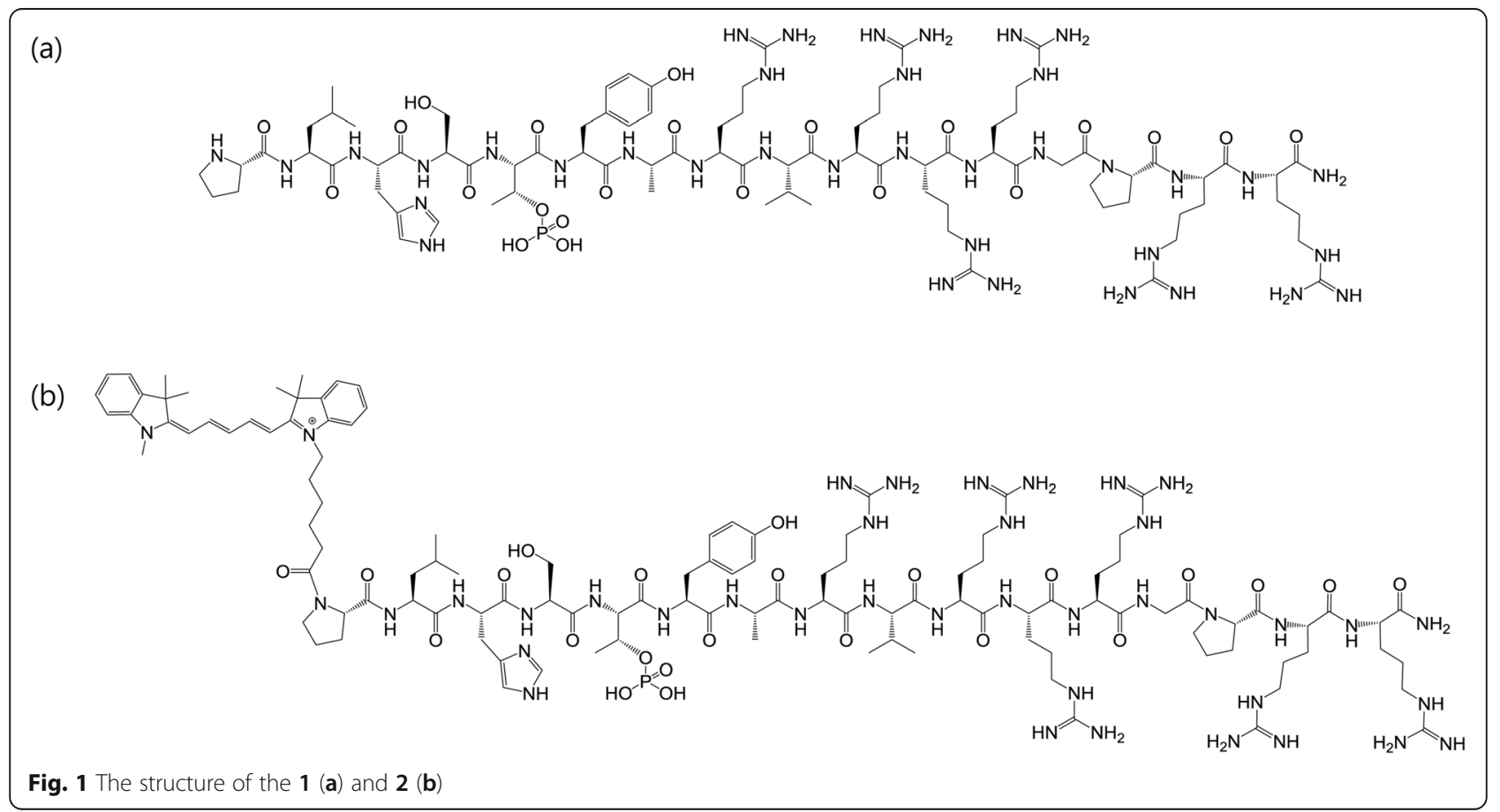


the resin with $2 \mathrm{~mL}$ of cleavage solution (TFA/TIS/ $\left.\mathrm{H}_{2} \mathrm{O}: 90 / 5 / 5\right)$ for $2 \mathrm{~h}$ and precipitated with cold ether. Peptide 1 was subsequently obtained as a white powder after purification with reverse-phase high-performance liquid chromatography (Vydac $\mathrm{C}_{18}$ column) with a linear gradient over $30 \mathrm{~min}$ of acetonitrile/0.1\% TFA from 5 to $90 \%$ at a flow rate of $1.5 \mathrm{~mL} / \mathrm{min}$ (YL 9100 HPLC system, Younglin, Korea). UV detection was carried out under a wavelength of $230 \mathrm{~nm}$. For the production of 2, Cy 5 moiety was introduced in the solution. 1 peptide powder (1 equiv.), cyanine 5 NHS ester (1 equiv.), and DIEA (5 equiv.) were dissolved in $2 \mathrm{~mL}$ of DMF. After $2 \mathrm{~h}$ of stirring at room temperature, the final product was purified by HPLC as above.

\section{In vivo optical imaging}

Animal experiments were carried out according to a protocol approved by the KBSI Animal Ethics Committee (KBSI-AEC-1816). For the xenograft tumor models, 6-week-old BALB/c nude male mice were subcutaneously inoculated with HeLa cancer cells $\left(5 \times 10^{6}\right)$ into their right front legs. Three weeks after the injection, when the tumor size (length $\times$ width $\times$ height, $\mathrm{mm}^{3}$ ) reached approximately $100-120 \mathrm{~mm}^{3}, 2(0.5 \mathrm{mg} / \mathrm{kg}$ body weight $/ 100 \mu \mathrm{L})$ was injected via the tail vein $(n=3)$. Optical images were acquired at 3,6, and $24 \mathrm{~h}$ after injection with the IVIS. Scanning was performed with 640 -nm excitation filters $(680,700$, and $720 \mathrm{~nm}$ for spectral unmixing), 680-nm emission filters, and a binning factor of 8. The fluorescence intensity of the obtained images was measured after regions of interest (ROIs) were drawn on the tumors and muscles. The quantitative value of the fluorescence intensity is expressed as photons per second per square centimeter per steradian $\left(\mathrm{p} / \mathrm{s} / \mathrm{cm}^{2} / \mathrm{sr}\right)$. Imaging was performed using the Living Image software (PerkinElmer, USA).

\section{Ex vivo optical imaging and biodistribution study}

The mice ( $n=3$ per time point) were sacrificed by $\mathrm{CO}_{2}$ inhalation at $6 \mathrm{~h}$ and $24 \mathrm{~h}$ after 2 injection. Heart, liver, spleen, kidney, muscles, and tumors were collected. Then, the obtained organs were scanned on a black paper with no light reflection under the same conditions as in the in vivo scan. Tumors and healthy organs were selected as ROIs. Fluorescence intensity of organs was obtained as described above.

\section{Results}

Synthesis of 1 and 2

We designed and synthesized $\mathbf{1}$ and $\mathbf{2}$ to determine the tumor diagnosis efficiency of the fluorescently labeled peptide (Fig. 1). Peptides were prepared using the Fmocbased SPPS method on rink amide resin and purified by HPLC (Fig. 2). The retention time of 1 was $13.3 \mathrm{~min}$ and that of the 2 was 22.2 min (Fig. 2). The peptides were identified by MALDI-TOF mass spectrometry; the molecular weight calculated for 1 (exact mass $\mathrm{m} / z=2057.1$ ) was determined as $m / z=2058.2$ and that for 2 (exact

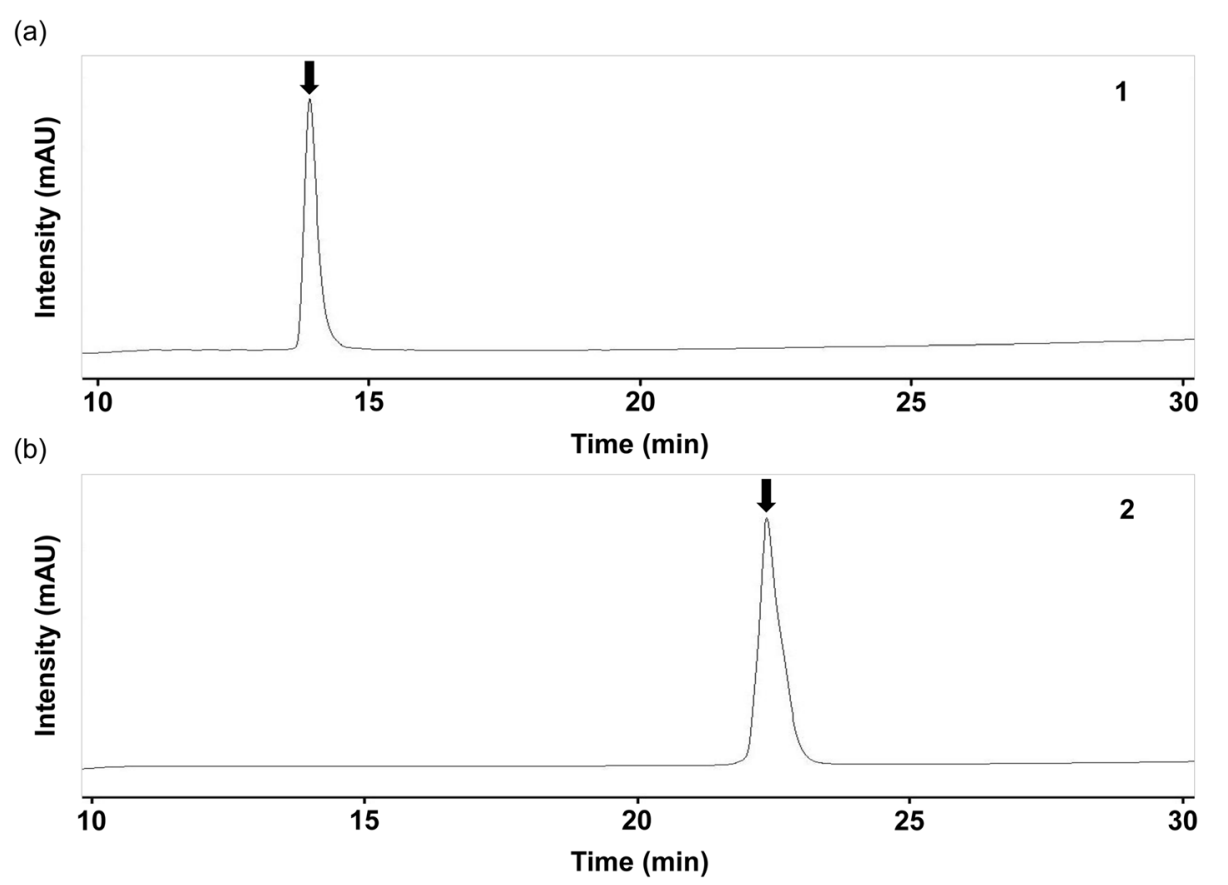

Fig. 2 HPLC profiles. HPLC showed retention time of $\mathbf{1}$ (a) and $\mathbf{2}$ (b). HPLC (Vydac $\mathrm{C}_{18}$ column) performed on a linear gradient over 30 min of acetonitrile/0.1\% TFA from $5 \%$ to $90 \%$ at a flow rate of $1.5 \mathrm{~mL} / \mathrm{min}$. UV detection was carried out under a wavelength of $230 \mathrm{~nm}$ 
mass $m / z=2522.3$ ) was actually $m / z=2522.3$ (Fig. 3). The synthesis yield of 1 was $69.5 \%$ (139 mg, $67.6 \mu \mathrm{mol}$, synthesis chemical purity $>97 \%$ ) and that of the 2 was $88 \%$ (150 mg, $59 \mu \mathrm{mol}$, synthesis chemical purity > 98\%).

\section{In vivo optical imaging}

For in vivo optical imaging, 2 was injected into HeLa tumor-bearing mice xenograft to determine the tumor-targeting and diagnosis effectiveness. Samples were analyzed at four time points, namely pre-injection, $3 \mathrm{~h}, 6 \mathrm{~h}$, and $24 \mathrm{~h}$ after injection. In all time points, the images presented high fluorescence accumulation in tumors (Fig. 4). The level of fluorescence intensity in tumors was $5.64 \pm 0.58 \times 10^{8} \mathrm{p} / \mathrm{s} /$ $\mathrm{cm}^{2} / \mathrm{sr}$ at $3 \mathrm{~h}, 2.62 \pm 0.26 \times 10^{8} \mathrm{p} / \mathrm{s} / \mathrm{cm}^{2} / \mathrm{sr}$ at $6 \mathrm{~h}$, and $1.04 \pm 0.07 \times 10^{8} \mathrm{p} / \mathrm{s} / \mathrm{cm}^{2} / \mathrm{sr}$ at $24 \mathrm{~h}$ (Fig. 5). However, fluorescence intensity decreased in other organs in a timedependent manner. Muscle tissues had a fluorescence intensity of $2.02 \pm 0.09 \times 10^{8} \mathrm{p} / \mathrm{s} / \mathrm{cm}^{2} / \mathrm{sr}$ at $3 \mathrm{~h}, 0.65 \pm 0.01 \times$ $10^{8} \mathrm{p} / \mathrm{s} / \mathrm{cm}^{2} / \mathrm{sr}$ at $6 \mathrm{~h}$, and $0.48 \pm 0.01 \times 10^{8} \mathrm{p} / \mathrm{s} / \mathrm{cm}^{2} / \mathrm{sr}$ at
$24 \mathrm{~h}$. The tumor-to-muscle ratios were 2.79 -fold at $3 \mathrm{~h}$, 3.98 -fold at $6 \mathrm{~h}$, and 2.15 -fold at $24 \mathrm{~h}$. The highest tumorto-muscle ratio was 3.98 at $6 \mathrm{~h}$ post-injection, which means that 2 could detect tumor cells with high selectivity $6 \mathrm{~h}$ after injection. These results demonstrate that $\mathbf{2}$ can effectively target tumors as an imaging probe.

\section{Ex vivo optical imaging and biodistribution}

Ex vivo optical imaging and biodistribution of 2 were examined in the heart, liver, spleen, kidney, muscles, and tumor samples obtained from the Hela xenograft-bearing mice $(n=3)$ at $6 \mathrm{~h}$ and $24 \mathrm{~h}$ after injection (Figs. 6 and 7$)$. The images showed high fluorescence intensity in the liver $\left(3.11 \pm 0.11 \times 10^{8} \mathrm{p} / \mathrm{s} / \mathrm{cm}^{2} / \mathrm{sr}\right.$ at $\left.6 \mathrm{~h}\right)$ and in the kidneys $\left(10.5 \pm 0.68 \times 10^{8} \mathrm{p} / \mathrm{s} / \mathrm{cm}^{2} / \mathrm{sr}\right.$ at $\left.6 \mathrm{~h}\right)$, which are known clearance organs of imaging probes. The levels of 2 uptake by tumors were also high. The ROI values in tumors were $1.20 \pm 0.12 \times 10^{8} \mathrm{p} / \mathrm{s} / \mathrm{cm}^{2} / \mathrm{sr}$ and $0.97 \pm 0.06 \times 10^{8} \mathrm{p} / \mathrm{s} / \mathrm{cm}^{2} / \mathrm{sr}$ at 6 and $24 \mathrm{~h}$, respectively.

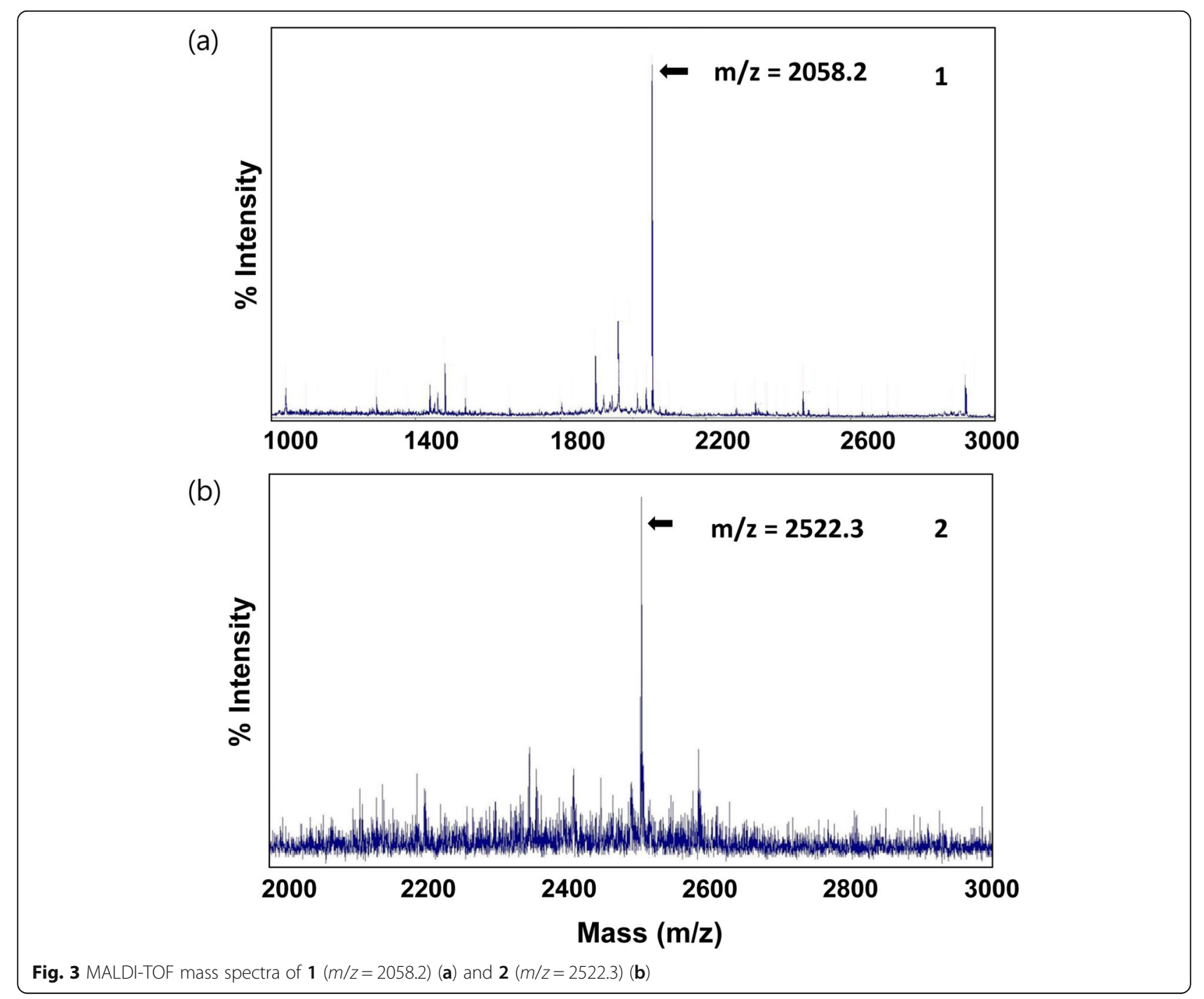




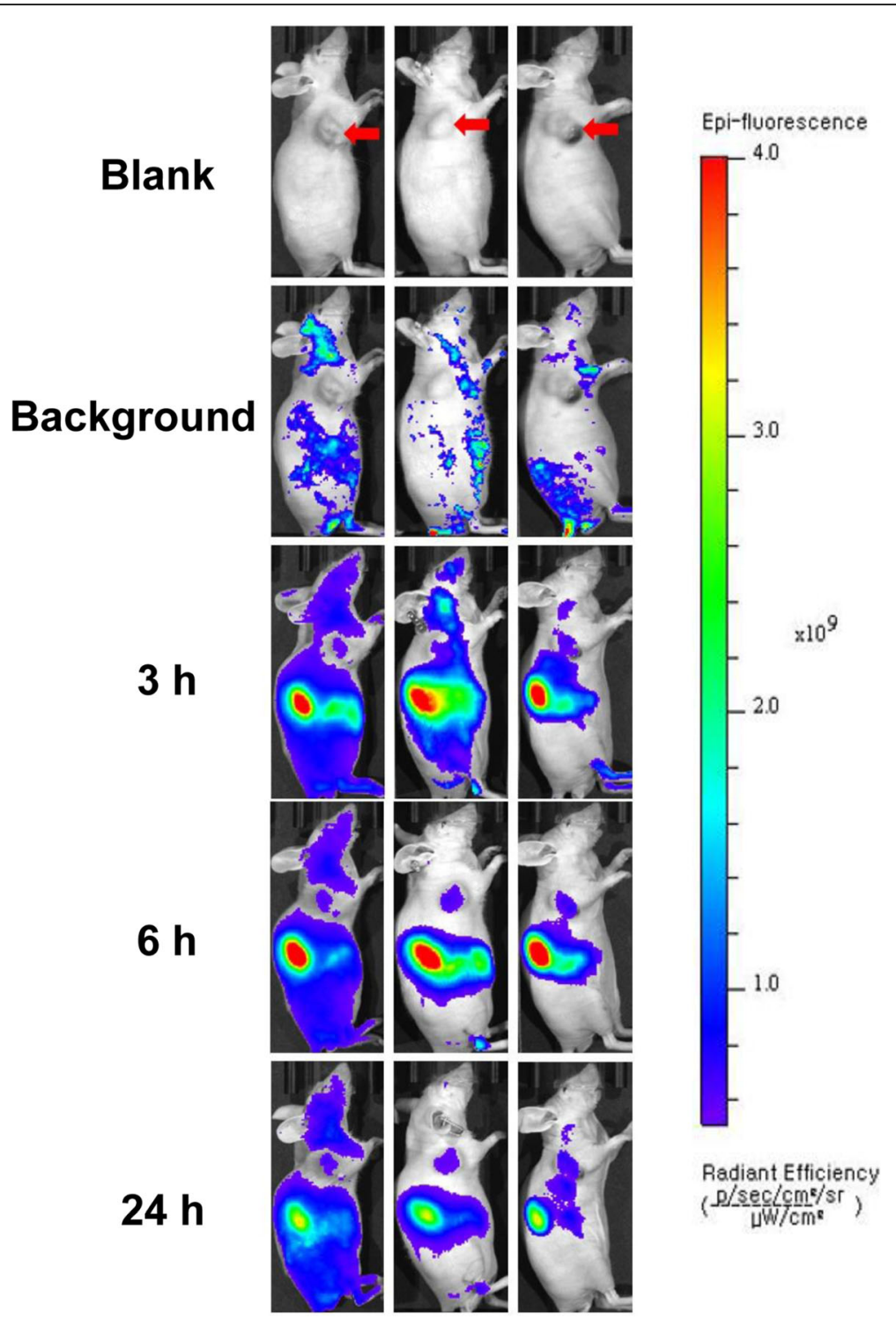

Fig. 4 Images from a representative experiment group mice with HeLa tumor xenograft model. Optical images were obtained at pre-injection, background, $3 \mathrm{~h}, 6 \mathrm{~h}$, and $24 \mathrm{~h}$ after injection of $\mathbf{2}(0.5 \mathrm{mg} / \mathrm{kg}$ body weight/100 $\mu \mathrm{L})$. Red arrows indicated the HeLa tumor

The tumor-to-muscle uptake ratio was 1.98 -fold at $6 \mathrm{~h}$ and 1.57 -fold at $24 \mathrm{~h}$. These results correlate with the in vivo optical imaging study for the diagnosis of tumors with 2.

\section{Discussion}

Plk1 is an essential protein for cell cycle regulation, cell division, and mitotic progression (Elia et al. 2003; Garcia-Alvarez et al. 2007). Moreover, since Plk1 is highly overexpressed in a variety of tumor cells, many Plk1 anticancer inhibitors have already been developed (Gilmartin et al. 2009; Watanabe et al. 2009). PLHSpT is one of the inhibitors designed to target
Plk1 but, as it is with other peptide drugs, its action is limited by the difficulty of intracellular delivery (Malik et al. 2007). The 47-57 TAT fragment is a well-known cell-penetrating peptide, and it is very useful for introducing proteins, peptides, and small molecules into cells (Gump and Dowdy 2007). Though its molecular mechanism to transport the combined materials into cells has still not been elucidated, this TAT peptide has been used in many applications. Our previous studies showed that 1 targets tumor cells in vitro to induce cell cycle arrest and apoptosis (Kim et al. 2014). Therefore, this study aimed to determine whether $\mathbf{1}$ targets tumors in vivo. 2 could be synthesized safely and efficiently using the 


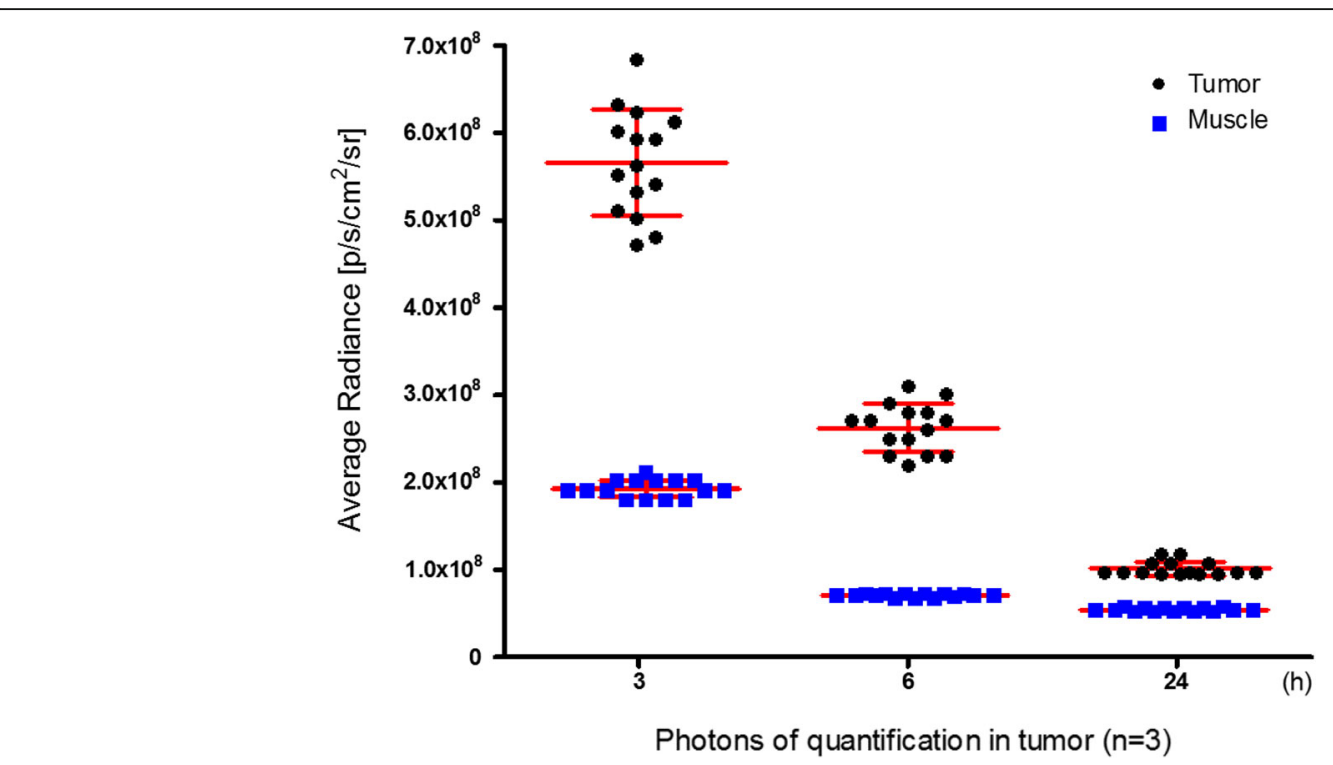

Fig. 5 ROls values of tumor and muscle were represented by photons per second per square centimeter per steradian ( $\mathrm{p} / \mathrm{s} / \mathrm{cm}^{2} / \mathrm{sr}$ ). Tumors and muscles were measured at least five points for each mouse. Experimental mouse groups are three in each group

Fmoc-amino acid SPPS method, and it could be purified with high quality by HPLC.

The main limitation of optical imaging is the low depth of penetration, which makes it difficult to observe deep organs in the body. However, it can be a useful guide during surgery, due to its real-time scanning potential and high sensitivity (Keereweer et al. 2013). There have been several tumor-targeting preclinical studies employing the advantages of optical imaging (Gao et al. 2004; Kang et al. 2013). Using optical imaging techniques, we confirmed that the fluorescent dye-conjugated peptide $\mathbf{2}$ correctly targeted mouse tumors in

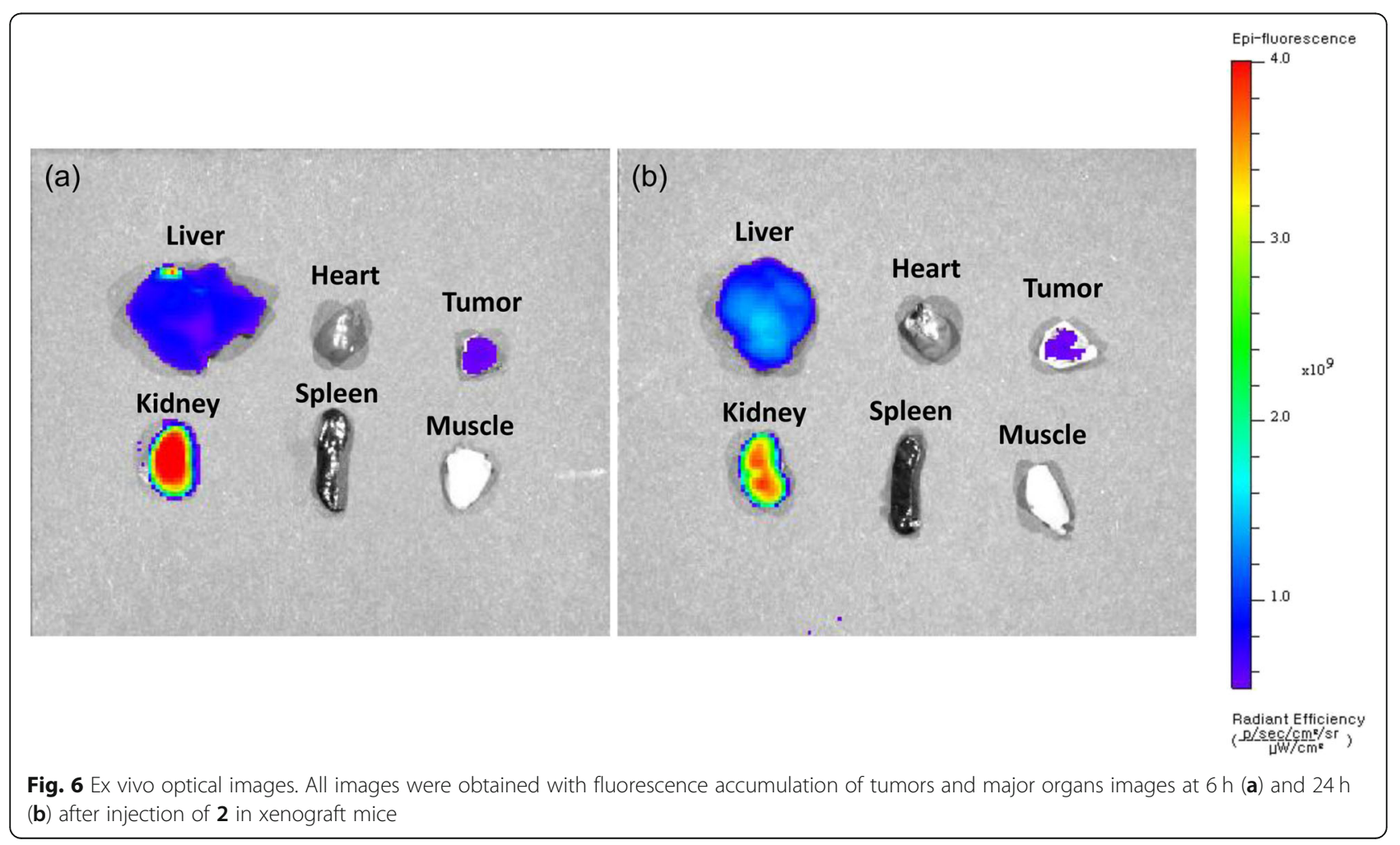




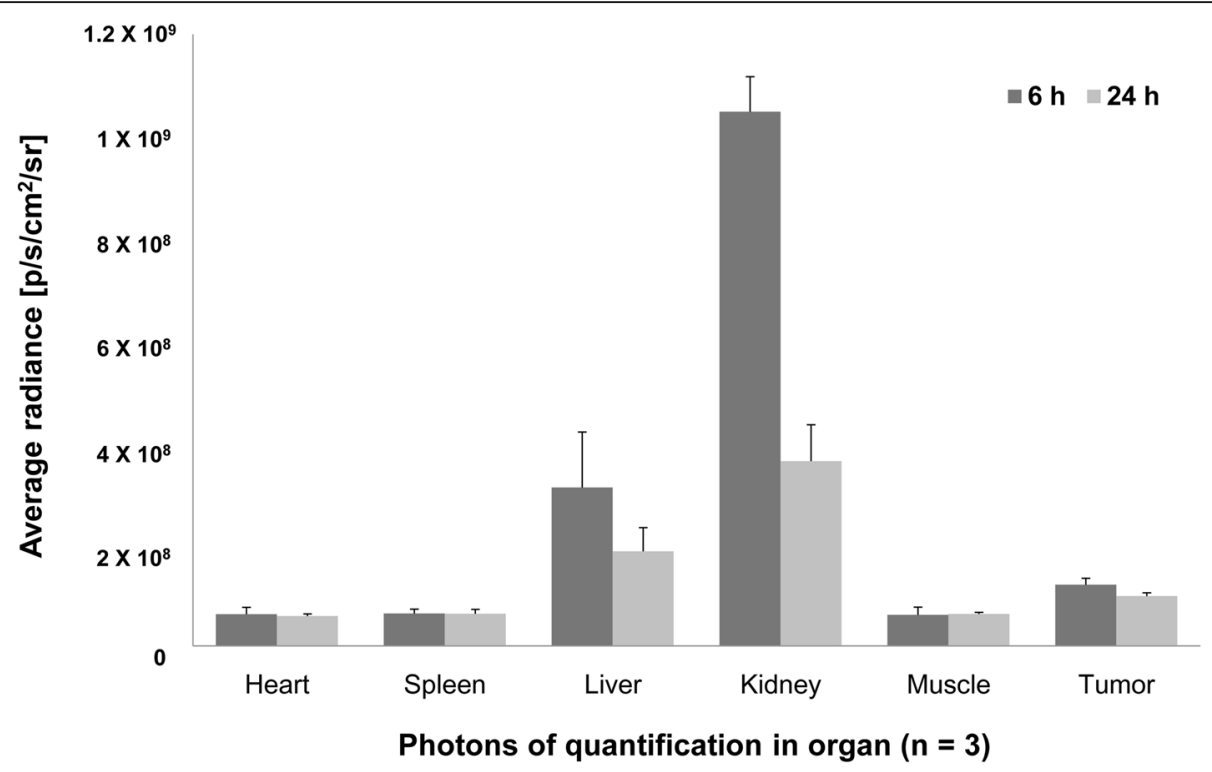

Fig. 7 Biodistribution of $\mathbf{2}$ in nude mice bearing Hela tumors at $6 \mathrm{~h}$ and $24 \mathrm{~h}$ post-injection. Tumors and major organs of fluorescence intensity values were measured and expressed by graph. The value represents the mean fluorescence intensity and the error bar represents SD

vivo (Fig. 4). Ex vivo images also showed great tumortargeting efficiency, and fluorescence intensity values were higher in tumors than in healthy organs (heart, spleen, and muscle) (Figs. 6 and 7). The clearance of probes is also an important issue in optical imaging. In our results, the liver displayed high fluorescence accumulation, probably due to the presence of the macrophage and mononuclear phagocyte system (Moghimi et al. 2001). The fact that the kidneys accumulated high levels of fluorescence that penetrated through the muscle layer and appeared in the in vivo imaging was fully expected, and it can be explained by the existing systemic circulation and renal clearance (Schmidt et al. 2010). For this reason, tumor cells were injected in the front legs of the mice rather than in their hind legs. Kidney clearance did not affect the tumor-targeting features of 2 . The low concentration of $2(0.5 \mathrm{mg} / \mathrm{kg})$ at $24 \mathrm{~h}$ showed that the tumor-targeted fluorescence tends to decrease rapidly over time. We tried to raise the concentration of 2 in the injection to 1,3 , or $5 \mathrm{mg} / \mathrm{kg}$, but, for all of them, the mice died within $5 \mathrm{~min}$ after injection. We believe the reason for this outcome should be the compound's toxicity. For long-time scans, it may be necessary to solve the peptide toxicity problem or to replace the BALB/c nude mice with a sturdier mouse species. Hence, the injection dose conditions still need to be optimized. In this study, we successfully produced a peptide conjugated to a fluorescent dye for tumor targeting using SPPS. This method is safe and convenient for long-chain peptide synthesis and allows for easy purification. Furthermore, we confirmed that the $\mathbf{2}$ peptide synthesized through this method could remarkably target tumors via optical imaging in vivo.

\section{Conclusions}

A new fluorescent dye-conjugated peptide, 2, was evaluated to target xenograft tumors in mice using optical imaging. Our results demonstrate that this peptide can specifically target tumors in vivo. Therefore, $\mathbf{2}$ is a good candidate for specific tumor binding and can be efficiently used as an imaging-based tumor diagnosis agent.

\section{Abbreviations}

Cy5: Cyanine 5; DIEA: Diisopropylethylamine; DMF: N,N-dimethylformamide; HBTU: O-Benzotriazole-1-yl- $N, N, N^{\prime}, N^{\prime}$-tetramethyluronium hexafluorophosphate; HOBt: Hydroxybenzotriazole; HPLC: High-performance liquid chromatography; IVIS: In vivo imaging system; PLHSpT: Pro-Leu-HisSer-p-Thr; PIk1: Polo-like kinase 1; ROls: Regions of interest; SPPS: Solid-phase peptide synthesis; TAT: Transactivator of transcription peptide;

TFA: Trifluoroacetic acid; TIS: Triisopropylsilane

\section{Acknowledgments}

This work was supported by the National Research Council of Science \& Technology (CAP-17-03-KRIBB) and by the Korea Basic Science Institute (T39703).

\section{Authors' contributions}

MSY, ESS, and HNK performed all experiments and data analyses. MSY and EKR wrote the manuscript. All authors read and approved the final version of the manuscript.

Funding

Not applicable.

\section{Availability of data and materials}

All data generated and analyzed in this study have been provided in the manuscript. 


\section{Competing interests}

The authors declare that they have no competing interests.

\section{Author details}

'Division of Bioconvergence Analysis, Korea Basic Science Institute, Ochang, Cheongju 28119, Korea. ${ }^{2}$ Bio-Analytical Science, University of Science and Technology, 217 Gajeong-ro Yuseong-gu, Daejeon 34113, Korea. ${ }^{3}$ Korea Basic Science Institute, Ochang, Cheongwon, Chungbuk 363-883, Republic of Korea.

Received: 20 May 2019 Accepted: 12 July 2019

Published online: 23 July 2019

\section{References}

Ahn M, Han Y-H, Park J-E, Kim S, Lee WC, Lee SJ, Gunasekaran P, Cheong C, Shin SY Sr, Kim H-Y. A new class of peptidomimetics targeting the polo-box domain of Polo-like kinase 1. J Med Chem. 2014;58:294-304.

Barr FA, Sillje HH, Nigg EA. Polo-like kinases and the orchestration of cell division. Nat Rev Mol Cell Biol. 2004;5:429-40.

Contag CH, Jenkins D, Contag PR, Negrin RS. Use of reporter genes for optical measurements of neoplastic disease in vivo. Neoplasia. 2000;2:41-52.

Craik DJ, Fairlie DP, Liras S, Price D. The future of peptide-based drugs. Chem Biol Drug Des. 2013:81:136-47.

Dai W. Polo-like kinases, an introduction. Oncogene. 2005;24:214-6.

Elia AE, Cantley LC, Yaffe MB. Proteomic screen finds pSer/pThr-binding domain localizing PIk1 to mitotic substrates. Science. 2003;299:1228-31.

Gao X, Cui Y, Levenson RM, Chung LW, Nie S. In vivo cancer targeting and imaging with semiconductor quantum dots. Nat Biotechnol. 2004;22:969-76.

Garcia-Alvarez B, de Carcer G, Ibanez S, Bragado-Nilsson E, Montoya G. Molecular and structural basis of polo-like kinase 1 substrate recognition: implications in centrosomal localization. Proc Natl Acad Sci U S A. 2007;104:3107-12.

Gilmartin AG, Bleam MR, Richter MC, Erskine SG, Kruger RG, Madden L, Hassler DF, Smith GK, Gontarek RR, Courtney MP, Sutton D, Diamond MA, Jackson JR, Laquerre SG. Distinct concentration-dependent effects of the polo-like kinase 1-specific inhibitor GSK461364A, including differential effect on apoptosis. Cancer Res. 2009;69:6969-77.

Gump JM, Dowdy SF. TAT transduction: the molecular mechanism and therapeutic prospects. Trends Mol Med. 2007;13:443-8.

Kang CM, Koo HJ, Lee KC, Choe YS, Choi JY, Lee KH, Kim BT. A vascular endothelial growth factor 121 (VEGF(121))-based dual PET/optical probe for in vivo imaging of VEGF receptor expression. Biomaterials. 2013;34:6839-45.

Keereweer S, Van Driel PB, Snoeks TJ, Kerrebijn JD, Baatenburg de Jong RJ, Vahrmeijer AL, Sterenborg HJ, Lowik CW. Optical image-guided cancer surgery: challenges and limitations. Clin Cancer Res. 2013;19:3745-54.

Kim SM, Chae MK, Lee C, Yim MS, Bang JK, Ryu EK. Enhanced cellular uptake of a TAT-conjugated peptide inhibitor targeting the polo-box domain of polo-like kinase 1. Amino Acids. 2014;46:2595-603.

Liu F, Park JE, Qian WJ, Lim D, Graber M, Berg T, Yaffe MB, Lee KS, Burke TR Jr. Serendipitous alkylation of a Plk1 ligand uncovers a new binding channel. Nat Chem Biol. 2011;7:595-601.

Long CM, Bulte JW. In vivo tracking of cellular therapeutics using magnetic resonance imaging. Expert Opin Biol Ther. 2009;9:293-306.

Malik DK, Baboota S, Ahuja A, Hasan S, Ali J. Recent advances in protein and peptide drug delivery systems. Curr Drug Deliv. 2007:4:141-51.

Margolis DJ, Hoffman JM, Herfkens RJ, Jeffrey RB, Quon A, Gambhir SS. Molecular imaging techniques in body imaging. Radiology. 2007;245:333-56.

Moghimi SM, Hunter AC, Murray JC. Long-circulating and target-specific nanoparticles: theory to practice. Pharmacol Rev. 2001;53:283-318.

Rehemtulla A, Stegman LD, Cardozo SJ, Gupta S, Hall DE, Contag CH, Ross BD. Rapid and quantitative assessment of cancer treatment response using in vivo bioluminescence imaging. Neoplasia. 2000;2:491-5.

Sauter AW, Wehrl HF, Kolb A, Judenhofer MS, Pichler BJ. Combined PET/MRI: one step further in multimodality imaging. Trends Mol Med. 2010;16:508-15.

Schmidt S, Gonzalez D, Derendorf H. Significance of protein binding in pharmacokinetics and pharmacodynamics. J Pharm Sci. 2010;99:1 107-22.

Takai N, Hamanaka R, Yoshimatsu J, Miyakawa I. Polo-like kinases (PIks) and cancer. Oncogene. 2005;24:287-91.

Tapfer A, Bech M, Velroyen A, Meiser J, Mohr J, Walter M, Schulz J, Pauwels B, Bruyndonckx P, Liu X, Sasov A, Pfeiffer F. Experimental results from a preclinical X-ray phase-contrast CT scanner. Proc Natl Acad Sci U S A. 2012; 109:15691-6.
Watanabe N, Sekine T, Takagi M, Iwasaki J, Imamoto N, Kawasaki H, Osada H. Deficiency in chromosome congression by the inhibition of Plk1 polo box domain-dependent recognition. J Biol Chem. 2009;284:2344-53.

Yang M, Baranov E, Jiang P, Sun FX, Li XM, Li L, Hasegawa S, Bouvet M, AlTuwaijri M, Chishima T, Shimada H, Moossa AR, Penman S, Hoffman RM. Whole-body optical imaging of green fluorescent protein-expressing tumors and metastases. Proc Natl Acad Sci U S A. 2000;97:1206-11.

\section{Publisher's Note}

Springer Nature remains neutral with regard to jurisdictional claims in published maps and institutional affiliations.

\section{Submit your manuscript to a SpringerOpen ${ }^{\circ}$ journal and benefit from:}

- Convenient online submission

- Rigorous peer review

- Open access: articles freely available online

High visibility within the field

- Retaining the copyright to your article

Submit your next manuscript at $\boldsymbol{\nabla}$ springeropen.com 